\title{
One Belt, One Road, One Way?
}

Citation for published version (APA):

Mau, K., \& Seuren, R. (2020). One Belt, One Road, One Way? Where European Exporters Benefit from the New Silkroad. Maastricht University, Graduate School of Business and Economics. GSBE Research Memoranda No. 024 https://doi.org/10.26481/umagsb.2020024

Document status and date:

Published: 15/09/2020

DOI:

10.26481/umagsb.2020024

Document Version:

Publisher's PDF, also known as Version of record

\section{Please check the document version of this publication:}

- A submitted manuscript is the version of the article upon submission and before peer-review. There can be important differences between the submitted version and the official published version of record.

People interested in the research are advised to contact the author for the final version of the publication, or visit the DOI to the publisher's website.

- The final author version and the galley proof are versions of the publication after peer review.

- The final published version features the final layout of the paper including the volume, issue and page numbers.

Link to publication

\footnotetext{
General rights rights.

- You may freely distribute the URL identifying the publication in the public portal. please follow below link for the End User Agreement:

www.umlib.nl/taverne-license

Take down policy

If you believe that this document breaches copyright please contact us at:

repository@maastrichtuniversity.nl

providing details and we will investigate your claim.
}

Copyright and moral rights for the publications made accessible in the public portal are retained by the authors and/or other copyright owners and it is a condition of accessing publications that users recognise and abide by the legal requirements associated with these

- Users may download and print one copy of any publication from the public portal for the purpose of private study or research.

- You may not further distribute the material or use it for any profit-making activity or commercial gain

If the publication is distributed under the terms of Article $25 \mathrm{fa}$ of the Dutch Copyright Act, indicated by the "Taverne" license above, 
Karsten Mau, Rosalie Seuren

One Belt, One Road, One Way? Where European Exporters Benefit from the New Silkroad

RM/20/024

ISSN: $2666-8807$

\section{GSBE}

Maastricht University School of Business and Economics

Graduate School of Business and Economics

\section{P.O Box 616}

NL-6200 MD Maastricht

The Netherlands 


\title{
One Belt, One Road, One Way? Where European Exporters Benefit from the New Silkroad
}

\author{
Karsten $\mathrm{Mau}^{*}$ \\ Maastricht University \\ School of Business and Economics
}

(SBE)

\author{
Rosalie Seuren ${ }^{\dagger}$ \\ Maastricht University \\ School of Business and Economics \\ (SBE)
}

September 15, 2020

\begin{abstract}
We analyze the trade effects of a new unfolding transport infrastructure in connection with China's Belt and Road Initiative (BRI). Using panel data for the years 1996-2018, featuring 27 exporting countries and 96 industries, we exploit variation in the timing and number of railway connections to estimate whether European countries benefit from increased export revenues and product variety of their shipments to China. We find that both increase and that also indirectly connected countries benefit. Using additional data on the mode of transport, we find that industries with intermediate time-sensitivity appear to increase their utilization of rail-freight to China the most and confirm that the overall increase in exports is driven by these industries.
\end{abstract}

JEL-Classification: F14, F15, R41

Keywords: China, Trade, Transport infrastructure, Belt and Road Initiative

*k.mau@maastrichtuniversity.nl

†seuren.rosalie@gmail.com 


\section{Introduction}

Trade infrastructure is a key determinant for both market access and trade volumes between countries. A well functioning infrastructure reduces frictions in the importing and exporting process as well as overall trade processing times. Both have been shown to explain differences in trade activity across countries (e.g. Djankov et al., 2010; Waugh, 2010).

In 2013, China's President Xi Jinping announced the launch of the Belt and Road Initiative (BRI), a transcontinental infrastructure investment project aimed at reviving the historical Eurasian Silk Roads. The BRI consists of two main elements: the Silk Road Economic Belt, which focuses on the development of land-based connections between China and Europe; and the 21st Century Maritime Silk Road, which involves sea transport routes and maritime infrastructure connecting China's East Coast to South Asia, Europe, and Africa. The former comprises the New Eurasia Land Bridge Economic Corridor, which consists of several intercontinental railway connections between China and Europe.

In this paper, we study the trade response to the development of this 'Corridor'. More specifically, we analyze how the gradual expansion of the railway network connecting China and Europe promotes exports of the latter. In doing so, we use different metrics to measure the expansion of the network and consider a number of different outcome variables. Besides the value of shipments, we look at trade creating effects of the Corridor for European exporters by analyzing the extensive product margin over time. Moreover, we use data on the transportation mode of European shipments to China in order to investigate in which sectors exports appear to switch towards time-saving (compared to sea shipments) or cost-saving (compared to air-freight) railway transport.

We exploit a detailed panel data set of countries' merchandise exports to China, spanning more than two decades up until 2018. Since 2011, and more broadly since 2014, we observe an increasing range of direct railway connections starting their operations on a regular schedule between China and Europe. Of the 23 European countries in our main sample

(i.e. the EU25, minus Cyprus and Malta), about two-thirds experience the establishment of a direct connection, so that we can compare their export performance relative to (i) non directly connected European countries, as well as to (ii) other high-income but non-European exporters, such as Japan and South Korea or Canada and the US.

To identify whether a country is connected to China by rail, we compile a list of announced and initiated train connections, which specifies the main end or starting points in China and Europe and the month when operations started. We also take into consideration the intraEuropean rail network and consider countries that are indirectly connected through the BRI, depending on their geographic proximity to a particular connection point in another 
European country. Along these lines, including non-European countries into our (i.e. East Asian and North American) comparison group enables us to fully account for potential spillover effects of the corridor on Europe's rail-connectivity and trade with China.

Moreover, we analyze how the share of European shipments to China realized via rail transport evolves as connections are being built. Our interest here focuses on the type of goods that show the strongest response, so that we can better understand which products or industries most likely benefit from these new connections. In terms of shipping times and costs, rail transport lies in between ocean container shipment (which has larger capacity, lower cost, and takes more time) and air-freight (which has lower capacity, higher cost and is faster). We, hence, expect a non-linear relationship between products' time-sensitivity and their propensity to switch to rail freight.

Our findings suggest that BRI train connections increased exports from Europe to China by about 10 percent on average, according to our baseline specification. While we find a generally robust positive relationship across specification and estimators (i.e. log-linear regression vs. PPML), we find statistically and quantitatively stronger evidence for exports to China when using non-European control groups (e.g. North America, represented by Canada and the US, and East Asia, represented by Japan and South Korea). This suggests that not only directly connected countries in Europe benefit from the BRI. Moreover, the performance differences are most pronounced relative to East Asian exporters, which could suggest that the BRI diverted some of the trade between China and those countries (and thus limiting the actual trade creation effects for China).

Besides the direct effects, we also find positive spillovers on exports by countries that are neighbors or geographically proximate to locations where the China-European railways stop. This is in line with our observations that the Corridor initially had only a few European end points from and to which freight could be forwarded. As such transmissions complicate the evaluation and quantification of the relationship between the BRI and European exports, we turn to an alternative data set where we observe exports by transportation mode and HS2 sector. This allows us, in a first step, to identify responsive industries and, in a second step, include this new sector dimension into our analysis. Results obtained from this refined identification strategy suggest an increase of exports by about 4-6 percent on average, and a similar increase in the number of products exported to China.

Regarding the responsiveness of different industries, we find substantial heterogeneity. On average, about one third of the HS2 industry sectors in our sample reveal significant increases in rail-freight to China, compared to other transportation modes. Comparing them to estimates of sector-level time sensitivity (as defined in Hummels and Schaur, 2013; Ciani and Mau, 2020), we report suggestive evidence of a non-monotonous inverse u-shaped 
relationship in 5 out of 6 of our specifications. While the last specification suggests that the relative likeliness of switching to rail-freight is orthogonal to time-sensitivity, the remaining ones suggest that industries where timely delivery is of intermediate importance may benefit the most from the BRI railway corridor.

Our paper makes several contributions to the empirical trade literature and in particular the literature that focuses on the importance of trade infrastructure. Several studies structurally estimate parameters of infrastructure-related trade costs to quantify its importance (Bougheas et al., 1999; Limão and Venables, 2001; Egger and Larch, 2017). Hummels (2007) reviews how advances in transport technologies since the 1950 s contributed to increased trade volumes and changing modes of transport, comparing ocean and air freight. Prominent examples with an explicit reference to railway networks are Donaldson and Hornbeck (2016) and Donaldson (2018), who focus on quantifying the impact of improved market access on the value of land and on price convergence respectively. Our approach is methodologically different in that we abstain from structural estimation. While being consistent with the gravity equation of international trade, we adopt a difference-and-difference type strategy to evaluate the revealed quantitative changes in trade pattern after the initiation of BRI railway operations.

Our study makes also a clear topical contribution by focusing on a recent and unprecedented, large scale infrastructure project. The BRI increasingly attracts interest of researchers in economics, as it offers novel approaches to answering a wide range of research questions (Li and Schmerer, 2017; Ruta et al., 2020). ${ }^{1}$ In this respect, our study is similar to Jackson and Shepotylo (2018) and Baniya et al. (2019), who employ a structural gravity model to estimate key parameters and quantify the potential effects of the BRI on trade with China. However, like most of the BRI related research to date, their studies are forwardlooking in the sense that potential costs or benefits are discussed based on counterfactual exercises. The only ex-post analysis we are aware of is Li et al. (2018), who focus primarily on Chinese exports to Europe. We partly build on their modelling approach, but improve on it by controlling more systematically for spurious correlation and potential omitted variable bias, using fixed effects and control variables that are constistent with the gravity equation. Moreover, extending the period of analysis by at least three years adds significant value to our study, as many connections started their regular operations only in 2014 or after.

\footnotetext{
${ }^{1}$ Besides trade, prominent questions relate to implications for maritime transport (e.g. Lee et al., 2018; Lau et al., 2018; Zhang et al., 2018; Chhetri et al., 2018), general logisitics and supply chains (Liu et al., 2018; Yang et al., 2018; Shao et al., 2018), or economic growth and development implications of the BRI (e.g. Enderwick, 2018; Cai, 2017). Questions naturally also go beyond economics and discuss also the important geopolitical role of the BRI, as The Economist highlights in a recent Special Report from February 2020: https://www.economist.com/special-report/2020/02/06/ china-wants-to-put-itself-back-at-the-centre-of-the-world.
} 
Accordingly, our results differ from their findings which seemed to question any detectable impact of the BRI on Europe's exports to China.

Our paper is structured as follows. In section 2 we present some background information about the BRI in general, and the new rail connections between China and Europe in particular. We also outline some theoretical channels through which we think the BRI might promote exports from Europe to China. In section 3 we describe the data used in our analysis and explain our empirical methodology, as well as our measurement and identification strategies. Section 4 presents our empirical results, including robustness checks and alternative specifications. Section 5 discusses the implications of our research and concludes.

\section{The 'One Belt, One Road' Initiative}

\subsection{General background and scope}

Announced in 2013, the 'One Belt, One Road' initiative (or Belt and Road Initiative; BRI) has been promoted as a project aimed at increasing connectivity between the European, Asian and African continents, and to strengthen their partnerships. Formally, there are five interdependent objectives: ${ }^{2}$ (i) enhance policy coordination; (ii) improve infrastructure connectivity; (iii) reinforce trade and investment cooperation; (iv) promote financial integration; and (5) support people-to-people collaboration.

According to McKinsey (2016) the BRI covers almost two-thirds of the world's population, one-third of global GDP and at least a quarter of world trade. However, there exists no formal list of participants so that the BRI can be considered as an open agreement where everyone is welcome to participate (World Bank, 2017). Also the involvement can be measured differently. In Table A1, we present one specific view on the scope of the BRI, which uses data from the China Global Investment Tracker (CGIT). ${ }^{3}$ It displays monthly BRIrelated foreign investment and construction contracts for Chinese firms across the world, up until December 2019. China's BRI activities reached out to 112 different countries on all continents. It is especially active in Africa and Asia, where almost all its investment and construction projects relate to the BRI. There is also a sizeable number of projects in Europe and the Americas, as well as a few transactions in South Korea and New Zealand. Japan, Australia, Canada and the US did not receive any BRI-related investment from China.

In the context of our study, we focus primarily on what can be called the "geographic approach" to BRI participation (World Bank, 2017). That is, we ask whether a transport

\footnotetext{
${ }^{2}$ See https://www.beltroad-initiative.com/belt-and-road/.

${ }^{3}$ The published by the American Enterprise Institute and the Heritage Foundation. The data can be accessed here: https://www.aei.org/china-global-investment-tracker/.
} 
Figure 1: Six economic corridors constitute the Belt

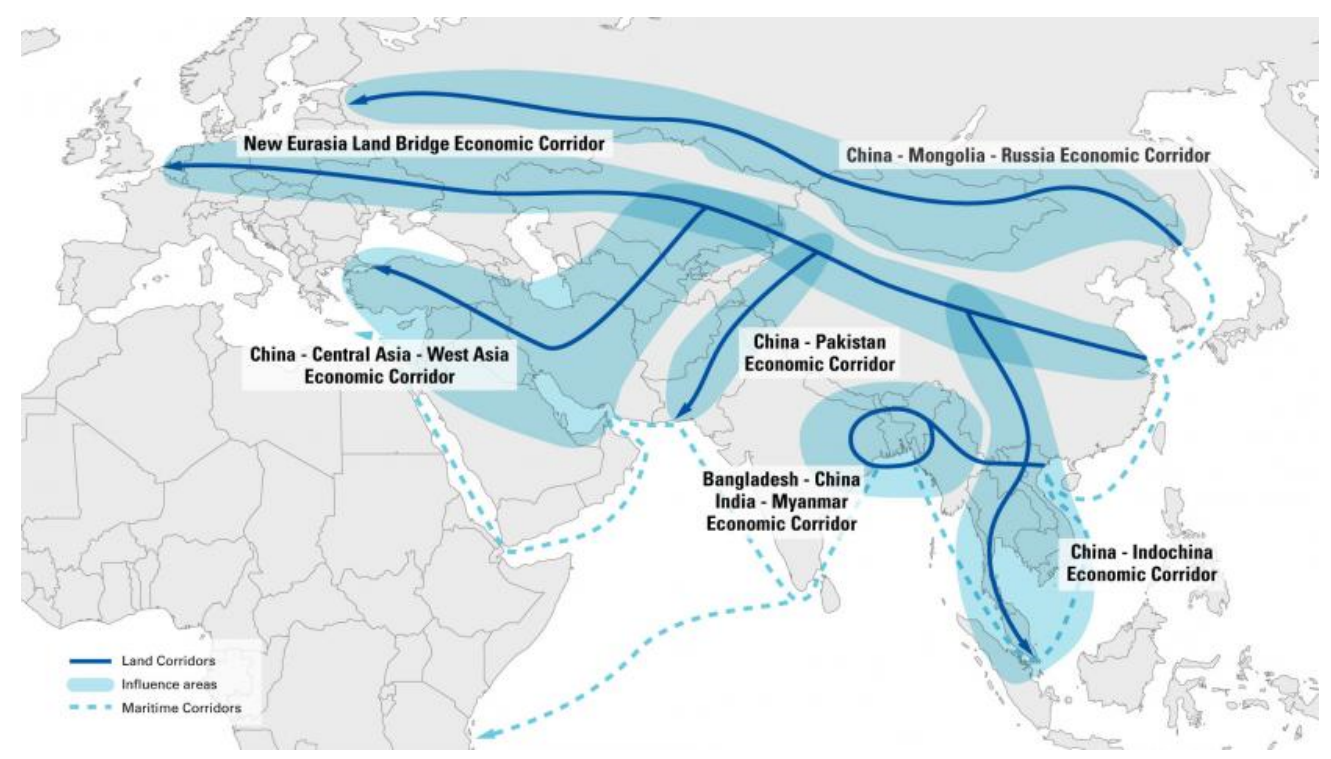

Source: International Road Transport Union (IRU.org, accessed: July 2020).

corridor runs through a particular country or not. As we can observe in Figure 1, there are six economic land corridors and a number of maritime corridors. While the land routes establish connections among countries in Asia and Europe, the maritime corridors complement those connections and involve additional countries mainly in the Middle East, North Africa, and the eastern coast of Sub-Saharan Africa. The New Eurasia Land Bridge Economic Corridor (henceforth: 'the Corridor') denotes one of two northern land routes and is the only one that establishes direct rail-freight connections between Western Europe and China. Detailed information about the European end points of the various train connection that started operating via the Corridor will constitute the basis for our measure of bilateral trade-infrastructure improvements.

\subsection{The 'Corridor': Connecting China and Europe}

The Corridor consists of a number of direct railway connections between Chinese and European cities. By the end of 2019, there were 15 of such connections, which we can include into our analysis. They operate at varying frequency and can be distinguished by the Chinese city to which the connection was initially established. ${ }^{4}$ Within Europe, there may be several destinations and their number increases as existing connections expand and new connections

\footnotetext{
${ }^{4}$ Many of these connections have several stops in China as well, so that here are numerous potential end points for European exports. Since we are unable to observe those or make any meaningful distinction between them, we are constrained to focusing on the number of distinct train routes.
} 
are launched. Almost all of the railway connections enter the European Union at the border of Belarus with Poland and carry forward through Germany.

Table A2 gives a detailed overview of the direct railway connections for which we collected information from various sources. The average reported distance travelled by a train amounts to slightly more than $10,000 \mathrm{~km}$ and ranges between about 8,000 and $13,000 \mathrm{~km}$ overall. Reported travel times for a rail connection vary between 11 and 26 days and average at 15 days. The much more eclectic information about the alternative maritime shipping times suggests about 40 days on average, more than 2.5 times as many days, which highlights the time advantage of rail transport over conventional sea shipment. ${ }^{5}$

Figure 2: Evolution of the BRI Corridor, number of connections to China since 2011

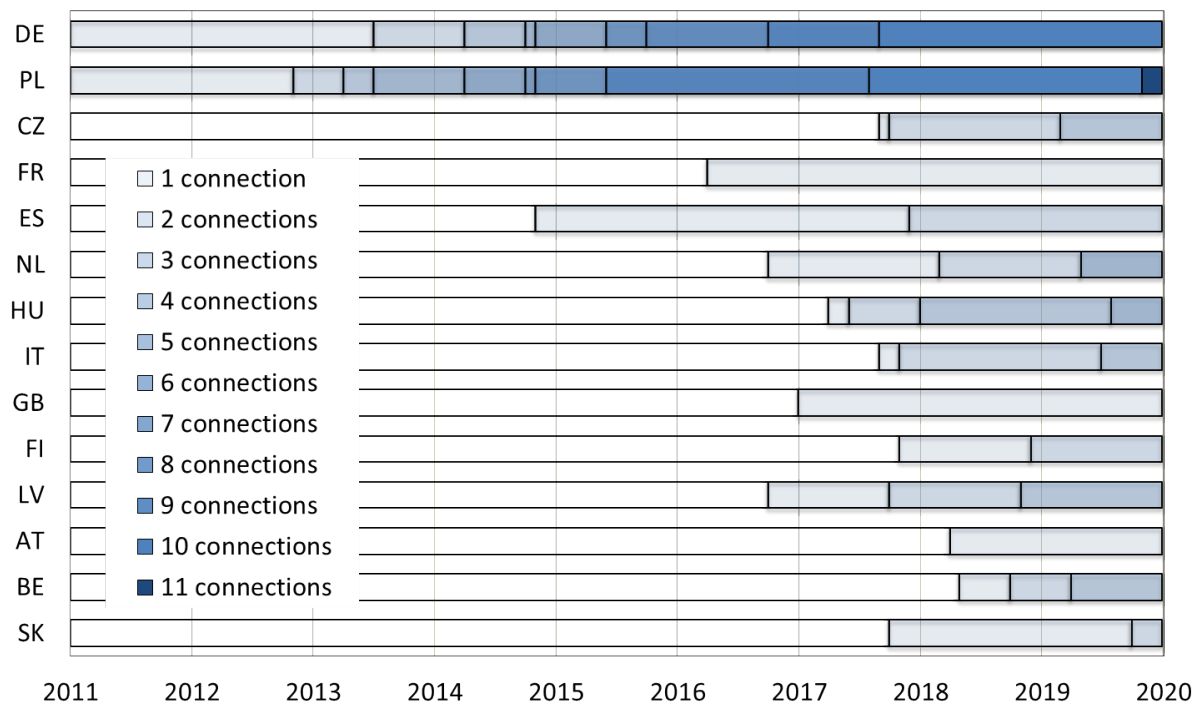

Note: Authors' calculations based on data from various source (see Table A2). Chart depicts number of direct train connections with China across European countries at monthly frequency. Belgium (BE) includes also Luxembourg.

In Figure 2 we show how the number of direct railway connections to China evolved over time and across Europe; variation we will exploit in our empirical analysis. It shows that direct connections via the Corridor differ substantially. Some countries are involved in almost all connections (and numbers increase over time), while others participate only recently or in a few lines. We also note that several (mostly geographically peripheral) European economies have not been at all directly connected to China via the Corridor. ${ }^{6}$ This does not necessarily

\footnotetext{
${ }^{5}$ Note that comparison of these numbers is complicated by that fact that shipping times within China (e.g. from the factory to the port and from port to final destination) are typically not quoted. Using data on bilateral sea distances from CERDI (Bertoli et al., 2016), maritime shipping between China and Europe bridges 14,200 to $22,400 \mathrm{~km}$, with an average of $18,800 \mathrm{~km}$.

${ }^{6}$ Considering the EU-25, the not directly connected countries are: Cyprus, Denmark, Estonia, Greece, Ireland, Malta, Portugal, Slovenia, Sweden.
} 
mean that these countries are unable to take advantage of the Corridor. Europe itself has a tightly-knit infrastructure network and many of the destinations are located at major transport and logistics hubs. We will take into consideration indirectly connected countries as well.

\subsection{Theoretical channels}

Direct theoretical channels through which BRI railway connections may affect international trade are threefold, but they all operate through the bilateral component $\phi_{n i}$ of a standard gravity equation, which can be derived from conventional trade models (Head and Mayer, 2014):

$$
X_{n i}=M_{n} S_{i} \phi_{n i}
$$

where the left-hand side variable $X_{n i}$ denotes the value of exports from country $i$ to destination $n, M_{n}$ denotes a general demand shifter and $S_{i}$ denotes a general supply shifter. The bilateral term $\phi_{n i}$ captures a wide set of exporter-importer specific trade determinants, such as geographic indicators (e.g. distance), cultural and historical indicators (e.g. language or colonial history), and bilateral contemporaneous political indicators (e.g. trade agreements).

We expect the BRI effects to operate through the distance-related channel. First, although the BRI does not change the geographic location of countries, it affects effectively travelled distances. We noticed earlier that they are reduced by about 50 percent compared to conventional ocean shipping routes between Europe and China. According to Chaney (2018), lower distances increase trade independently of trade policies and transport technology, as they affect the network structure of internationally operating firms. Second, lower travel distances and faster transportation technology reduce the time it takes for a good to be shipped to a specific destination. Hummels and Schaur (2013) show that shorter delivery times have real trade effects as they enter the objective function of importers. Empirical evidence by Djankov et al. (2010) and Ciani and Mau (2020) supports this mechanism and also that travel times are of variable importance across industries. Finally, shipping routes, duration and transportation mode determine the charges that have to be paid. While per unit charges should be lower for shorter travels (Hummels and Skiba, 2004), they are likely to be higher in the case of capacity constraints for a specific mode of transport. Compared to ocean shipping, we expect charges and transportation costs to be higher for trade via the BRI, but still considerably lower than air-freight. ${ }^{7}$

Altogether, the three different channels (distance, time, and transport charges) are likely

\footnotetext{
${ }^{7}$ Anecdotal evidence from Li et al. (2018) suggests 80 percent lower shipping charges for rail transport compared to air-freight.
} 
to adjust in a way that trade barriers between China and the EU are reduced. To what extent this stimulates trade is an empirical question, but we expect to observe adjustments in both overall export revenues and at the extensive margin (i.e. the number of different types of goods exported). The latter will be the case if the new trade routes lower trade barriers for certain transport- and time-sensitive products in such a way that they start being exported to China. In fact, adjustments may differ across industries if they are differentially sensitive to timely delivery. As air-freight remains a faster but more expensive modal choice, trade in goods with intermediate levels of time-sensitivity might be most responsive to the new BRI railway connections.

\section{Empirical model and data}

\subsection{Data and sample selection}

To analyze the effect of newly established BRI connections on Europe's exports to China, we use comprehensive information from the CEPII BACI database (Gaulier and Zignago, 2010). It reports annual bilateral trade flows between more than 200 countries at the 6digit Harmonized System level (HS6), which distinguishes about 5,000 different product categories. Using the most recently released version, we observe trade for the period 19962018. By counting the number of HS6 products a country exports to China in a given year, we attempt to capture the extensive product margin. In doing so, we assume that unreported trade flows in the data reflect negligible amounts of trade or true export zeros.

For the main part of our analysis, we aggregate the data to the 2-digit HS level (HS2) and obtain two outcome variables. ${ }^{8}$ First, the revenues (measured in thousands of current US dollars) earned by country $i$ from exporting goods of HS2 chapter $k$ to China in year $t$, $X_{i k t}$. Second, the number of HS6 goods within HS2 chapter $k$, shipped by country $i$ to China in year $t, N_{i k t}$. According to our discussion above, both variables should reveal a positive relationship with BRI railway connections.

Our baseline estimation sample considers exports by $23 \mathrm{EU}$ member states (i.e. the EU25, minus Cyprus and Malta) and 4 non-European high-income countries (i.e. Canada, Japan, South Korea, and the US). The latter are included as an additional control group, which we believe is economically comparable to EU25 exporters but not connected to China via the BRI. This enables us to investigate potential spillover effects of the BRI connections within Europe. To detect those, we will report our main results for alternative compositions

\footnotetext{
${ }^{8} \mathrm{HS} 2$ chapters range from 1 to 97 in our data. Chapter 77 is currently not used by the World Customs Organization (WCO), so that there are 96 sectors overall.
} 
of sub-samples of exporters.

\section{$3.2 \quad$ Empirical model}

\subsubsection{Baseline estimation equation}

Export revenue equation. We adopt the following empirical model (expressed in logs) to estimate the effect of BRI connections on exports to China:

$$
\ln X_{i k t}=\beta \operatorname{train}_{i t}+\gamma^{\prime} \mathbf{Z}_{i k t}+\mu_{k t}+\mu_{i k}+\varepsilon_{i k t},
$$

where the dependent variable measures the (log) dollar value of export revenues from shipments to China and $\operatorname{train}_{i t}$ indicates whether exporter $i$ was connected to China via the BRI at time $t$. We include two types of multi-dimensional fixed effects to establish consistency with the gravity equation: $\mu_{k t}$ captures China's demand shifter and varies across industries and over time, independently of which country is exporting. ${ }^{9} \quad \mu_{i k}$ captures time-invariant bilateral and industry-specific trade barriers between exporter $i$ and China. Since exporteryear fixed effects would be perfectly collinear with our main variable of interest, $\operatorname{train}_{i t}$, we proxy the supply shifter with control variables $\mathbf{Z}_{i k t}$. In our revenue equation, we will use $i$ 's global exports in HS2 sector $k$ and year $t$, which is defined as $X_{i k t}^{W} \equiv \sum_{n} X_{n i k t}$.

Export diversification equation. Whenever we estimate the number of goods exported to China, we include two additional control variables. First, we include the equivalent to global export revenues by counting how many different HS6 products exporter $i$ ships to any destination at time $t$, within HS2 chapter $k\left(N_{i k t}\right)$. Second, to account for the fact that our count variable has an upper bound, we interact our main variable of interest with $i$ 's degree of diversification in $k$ at the beginning of our sample period $\left(\operatorname{train}_{i t} \times\left[N_{i k}^{96} / N_{k}^{\max }\right]\right)$. The ratio $\left[N_{i k}^{96} / N_{k}^{\max }\right]$ is bound between zero and one and denotes the fraction of HS6 products within an HS2 chapter, $i$ exported to China at $t_{0}=1996$. We expect that initially high levels of diversification result in systematically lower rates of diversification after getting connected via the BRI, simply because no further diversification can be observed with our count measure.

Estimation methods. Even with fairly aggregated data and a sample of frequently trading countries, export zeros result in missing (or even omitted) information when estimating a log-linear model like Equation (2). Santos-Silva and Tenreyro (2006) formulate a more

\footnotetext{
${ }^{9}$ Since China is the only destination we observe, importer subscripts $n$ are omitted here.
} 
general critique on the use of log-linear estimation and suggest a Poisson-Pseudo-MaximumLikelihood (PPML) estimator, which has since become widely applied in the empirical trade literature. The corresponding model to estimate export revenues takes the following form:

$$
X_{i k t}=\exp \left\{\beta \operatorname{rrain}_{i t}+\gamma^{\prime} \mathbf{Z}_{i k t}+\mu_{k t}+\mu_{i k}\right\} \times \nu_{i k t}
$$

and represents simply the multiplicative version of the log-linear specification above. By avoiding any variable transformation that complicates the presence of zeros, the PPML estimator is able to exploit the full information of the data, including absence of trade (i.e. zeros). For our baseline findings we will report results obtained from both log-linear least squares and PPML estimation.

\subsubsection{Measurement}

Our trade data and estimation methods are widely used in the empirical trade literature. However, our measurement and identification strategies are novel, given that we are the first to estimate the effect of BRI connections on exports in a non-structural way. Hence, we have to be aware of the caveats associated with measurement and with potentially confounding effects or endogeneity. This is important, because our data does not allow us to observe the true amount of trade that is realized via a BRI rail connection. What we do observe is (i) whether and since when a particular country is connected to China via the BRI, (ii) where the connection starts or ends in China and (iii) how much a country exported to China before and after it became connected.

With this information at hand, we construct three different measures for our main variable of interest, $\operatorname{train}_{i t}$. First, we define it as a simple binary indicator variable, which takes a value equal to one as soon as a direct connection has been launched (see Table A2). ${ }^{10}$ Although this measure is fairly crude, it allows us to infer whether the pure existence of a direct rail connection reveals differential export performance compared to non-connected countries. Our second measure takes into account the number of different connections to China. As outlined in section 2, rail-freight routes differ by their final destinations in China and we argue that this might be relevant, given its geographic size and internal distances. By counting the number of railway connections between exporter $i$ and China, we no longer estimate the overall effect of a BRI connection, but rather the marginal effect of adding one additional connection. In a similar fashion, our third measure, which takes into account the time that has elapsed since the first connection has been launched, will inform us about the

\footnotetext{
${ }^{10} \mathrm{~A}$ value in between 0 and 1 is assigned in the year when the connection started to operate, whenever it started later than January. In that case, $\operatorname{train}_{i t}=(13-$ month $) / 12$.
} 
effect of being connected via the BRI for one additional year.

\subsubsection{Identification}

Despite using alternative measures and substantial variation in our data (see Figure 2), we cannot rule out that our results will be biased due to unobserved contemporaneous factors. While we do not believe that reverse causality plays a major role here, ${ }^{11}$ we are aware that also indirect connections might play a role and promote exports for countries that are neighbors of or proximately located to a directly connected country. Such indirect connections could result in a downward bias in our estimates, even though having non-European exporters in our control group might address part of this issue. In our robustness checks, we experiment with alternative definitions of being connected.

Another potential caveat of identification is that we cannot observe the mode of transport. As long as this is not the case, we are unable to verify whether any change in export performance actually takes place via the BRI railway connections. To address this concern, we will report results from an alternative data set of (only) European exporters, which features information on the transport mode. We will exploit this information also to determine sectors that increasingly rely on rail transport when exporting to China, after getting connected, and to revisit our baseline findings by adding this sectoral dimension to estimate the BRI effect on EU exports.

A final threat to identification is that we do not observe the frequency and capacity of shipments via a particular train connection. It is possible, for instance, that a country gets connected at some point (resulting in $\operatorname{train}_{i t}=1$ ), but operations are discontinued due to low profitability. In that case, we would have to set train $_{i t}$ back to zero. Unfortunately, such detailed information is not available and prevents us from distinguishing these and other qualitative dimensions across train different connections and over time, which might result in an attenuation bias and lack of precision of our coefficient estimates. While we have no possibility to address this issue of measurement error directly, we will keep in mind that our reported findings reflect average estimated effects and that responses in trade activity for specific individual connections might differ substantially.

\footnotetext{
${ }^{11}$ Reverse causality would imply that a train connection is established due to increased trade. While this might be true for the decision to build any connection between China and Europe, the exact location within Europe is likely to be determined by logistical factors in a fashion that major transport hubs and geography are preferred over more remote locations. Along these lines, the way a handful of European sea ports dominate the EU's maritime trade with the rest of the world, a few logistic hubs appear to dominate EU's railway connections to and from China.
} 


\section{Empirical findings}

\subsection{Baseline results for export revenues and diversification}

Export revenues. Table 1 reports our baseline results for the value of exports to China, showing point estimates obtained from 24 different specifications. Specifications differ in terms of their estimation method (i.e. log-linear least squares versus PPML), country samples and subsamples, and in terms of the variable that measures BRI connections (see Panels A through C). In most of these specifications, we observe a positive and statistically significant relationship between countries' exports and a railway connection to China via the Corridor.

Table 1: Export revenues and direct railway connection to China, baseline results

\begin{tabular}{|c|c|c|c|c|c|c|c|c|}
\hline \multirow{3}{*}{$\begin{array}{l}\text { Est. method: } \\
\text { Sample }\end{array}$} & $(1)$ & $(2)$ & (3) & (4) & $(5)$ & $(6)$ & $(7)$ & $(8)$ \\
\hline & \multicolumn{4}{|c|}{ Least Squares (log-lin.) } & \multicolumn{4}{|c|}{ PPML } \\
\hline & Full & Treat+EU & Treat+NA & Treat $+\mathrm{EA}$ & Full & Treat $+\mathrm{EU}$ & Treat+NA & Treat+EA \\
\hline $\begin{array}{l}\text { Panel A: Binar } \\
\text { train }_{i t} \text { (binary) }\end{array}$ & $\begin{array}{l}\text { indicate } \\
0.169^{* *} \\
(0.034)\end{array}$ & $\begin{array}{c}\text { r of connect } \\
0.109^{* *} \\
(0.037)\end{array}$ & $\begin{array}{l}0.083^{*} \\
(0.034)\end{array}$ & $\begin{array}{l}0.178^{* *} \\
(0.045)\end{array}$ & $\begin{array}{l}0.091^{\text {** }} \\
(0.026)\end{array}$ & $\begin{array}{l}-0.007 \\
(0.023)\end{array}$ & $\begin{array}{c}0.046^{*} \\
(0.019)\end{array}$ & $\begin{array}{l}0.119^{* *} \\
(0.028)\end{array}$ \\
\hline $\begin{array}{l}\text { Panel B: Numb } \\
\text { train }_{i t} \text { (count) }\end{array}$ & $\begin{array}{c}\text { er of con } \\
0.033^{* *} \\
(0.005)\end{array}$ & $\begin{array}{l}\text { lections } \\
\qquad .024^{* *} \\
(0.005)\end{array}$ & $\begin{array}{l}0.021^{* *} \\
(0.005)\end{array}$ & $\begin{array}{l}0.030^{* *} \\
(0.006)\end{array}$ & $\begin{array}{l}0.010^{* *} \\
(0.003)\end{array}$ & $\begin{array}{c}0.007^{*} \\
(0.003)\end{array}$ & $\begin{array}{l}0.007^{*} \\
(0.003)\end{array}$ & $\begin{array}{l}0.016^{* *} \\
(0.003)\end{array}$ \\
\hline $\begin{array}{l}\text { Panel C: Years } \\
\text { train }_{i t} \text { (years) }\end{array}$ & $\begin{array}{c}\text { since firs } \\
0.048^{* *} \\
(0.008)\end{array}$ & $\begin{array}{c}\text { connection } \\
0.036^{* *} \\
(0.008)\end{array}$ & $\begin{array}{l}0.030^{* *} \\
(0.008)\end{array}$ & $\begin{array}{l}0.045^{* *} \\
(0.009)\end{array}$ & $\begin{array}{l}0.016^{* *} \\
(0.005)\end{array}$ & $\begin{array}{c}0.009 \\
(0.006)\end{array}$ & $\begin{array}{l}0.011^{*} \\
(0.005)\end{array}$ & $\begin{array}{l}0.024^{* *} \\
(0.005)\end{array}$ \\
\hline $\begin{array}{l}\text { Observations } \\
\text { Clusters (it) }\end{array}$ & $\begin{array}{c}46,403 \\
598\end{array}$ & $\begin{array}{l}37,670 \\
506\end{array}$ & $\begin{array}{c}30,014 \\
368\end{array}$ & $\begin{array}{c}30,031 \\
368\end{array}$ & $\begin{array}{c}55,751 \\
598\end{array}$ & $\begin{array}{c}46,951 \\
506\end{array}$ & $\begin{array}{c}34,487 \\
368\end{array}$ & $\begin{array}{c}34,487 \\
368\end{array}$ \\
\hline
\end{tabular}

Note: Table shows coefficient estimates of the impact of direct BRI railway connections on the value of exports from Europe and China. Samples distinguish countries included, where Treat+EU corresponds to the EU23 (i.e. EU25 minus Cyprus and Malta); Treat + NA corresponds to the 14 connected European countries as well as Canada and the US; and Treat + EA corresponds to the 14 connected European countries as well as Japan and South Korea. Results in columns (1) and (5) use the full sample, which includes the EU23 plus NA plus EA. All specifications include HS2 sector-year and HS2 sector-exporter fixed effects, and a control variable for total sectoral exports, $X_{i k t}$. Standard errors in parentheses adjusted for clustering at exporter-year level. Statistical significance: $\mathrm{a}=\mathrm{p}<0.01,{ }^{* *}=\mathrm{p}<0.05,{ }^{*}=\mathrm{p}<0.1$.

Looking at the full sample in Panel A, columns (1) and (5) report between 9 and 17 percent higher export revenues in China upon the initiation of a direct railway connection (relative to the non-connected countries in Europe, North America and East Asia). Panel B suggests that each additional direct connection from country $i$ to China is associated with a 1-3 percent relative increase in exports. In Panel $\mathrm{C}$ we find that, on average, each additional year of direct rail freight operations are associated with 1.5-5 percent higher export revenues relative to non-connected economies. Comparing our log-linear specifications to the PPML estimates, we notice that the latter produces more conservative estimates throughout. 
In several specifications the estimated differences reveal most strongly in samples where the control group is composed of Japan and South Korea, as indicated in columns (4) and (8). In contrast to this, relative exports among the European countries indicate only a minor advantage of having a direct connection, as shown in columns (2) and (6). This might suggest that the EU as a whole benefits from the BRI through increased exports to China. Moreover, the fact that the revealed relative export performance appears to depends partly on the control group might suggest that improved market access for Europe either displaced some of the East Asian countries' exports to China, or that certain underlying trends have not appropriately been controlled for. These factors make identification more difficult and we will attempt to address them in the following subsection below.

Market access and diversification. Table 2 reports our findings for extensive margin effects, which we measure by counting the number of distinct HS6 products each country exports to China within their HS2-sector level exports. Moreover, as explained in the previous section, we account for the fact that our diversification variable has an upper bound, $N_{k}^{\max }$. Hence, we include an interaction of our main variable of interest with exporter $i$ 's initial stage of diversification in sector $k$. As expected, the interaction term produces a negative and statistically significant coefficient. ${ }^{12}$

Regarding the estimated relationship between the BRI connections and export diversification, we find a positive and highly significant relationship. Overall, connected countries experienced a relative increase in their product range by almost 30 percent. Each additional connection and the longer these connections are operating, the larger is this advantage. As in our previous results for export revenues, we observe that most of this increase appears to materialize vis-à-vis the two East Asian exporters in our sample. However (and partly in contrast to the previous results), they do not fully drive the overall findings reported in columns (1) and (5). Improved market access opportunities appear to result also relative to the US and (to a smaller extent) also relative to not directly connected European countries.

\subsection{Indirect connections and robustness}

Alternative measures and controls. Since our baseline specifications considered only the relationship between exports and direct BRI railway connections to China, we did not allow neighbors or very nearby countries to benefit. Such an approach might be too restric-

\footnotetext{
${ }^{12}$ The ratio displayed in the table is equal to 1 , whenever exporter $i$ already exported all the HS6 products that fall into a respective HS2 sector at the beginning of our sample period (in 1996). It is zero if it did not export any HS6 product from that sector initially. The former case rules out any further diversification whereas the latter case makes it very likely to occur.
} 
Table 2: Export diversification and direct railway connections to China, baseline results

\begin{tabular}{|c|c|c|c|c|c|c|c|c|}
\hline \multirow{3}{*}{$\begin{array}{l}\text { Est. method: } \\
\text { Sample }\end{array}$} & (1) & (2) & & (4) & (5) & (6) & (7) & (8) \\
\hline & \multicolumn{4}{|c|}{ Least Squares (log-lin.) } & \multicolumn{4}{|c|}{ PPML } \\
\hline & Full & Treat+EU & Treat+NA & Treat+EA & Full & Treat+EU & Treat+NA & Treat+EA \\
\hline $\begin{array}{l}\text { Panel A: Binar } \\
\text { train }_{i t} \text { (binary) }\end{array}$ & $\begin{array}{l}\text { indicato } \\
0.191^{* *} \\
(0.027)\end{array}$ & $\begin{array}{c}\text { of connectio } \\
0.119^{* *} \\
(0.024)\end{array}$ & $\begin{array}{l}0.209^{* *} \\
(0.027)\end{array}$ & $\begin{array}{l}0.253^{* *} \\
(0.032)\end{array}$ & $\begin{array}{l}0.302^{* *} \\
(0.038)\end{array}$ & $\begin{array}{l}0.176^{* *} \\
(0.035)\end{array}$ & $\begin{array}{l}0.324^{* *} \\
(0.040)\end{array}$ & $\begin{array}{l}0.367^{* *} \\
(0.041)\end{array}$ \\
\hline $\begin{array}{l}\times \text { init. div. } \\
\left(n_{i k}^{96} / n_{k}^{\max }\right) \\
\end{array}$ & $\begin{array}{c}-0.585^{* *} \\
(0.048) \\
\end{array}$ & $\begin{array}{c}-0.615^{* *} \\
(0.053) \\
\end{array}$ & $\begin{array}{c}-0.557^{* *} \\
(0.049) \\
\end{array}$ & $\begin{array}{c}-0.553^{* *} \\
(0.048) \\
\end{array}$ & $\begin{array}{c}-0.507^{* *} \\
(0.052) \\
\end{array}$ & $\begin{array}{c}-0.486^{* *} \\
(0.054) \\
\end{array}$ & $\begin{array}{c}-0.536^{* *} \\
(0.053) \\
\end{array}$ & $\begin{array}{c}-0.567^{* *} \\
(0.054) \\
\end{array}$ \\
\hline $\begin{array}{l}\text { Panel B: Numb } \\
\text { train }_{i t} \text { (count) }\end{array}$ & $\begin{array}{c}\text { er of conn } \\
0.035^{* *} \\
(0.006)\end{array}$ & $\begin{array}{l}\text { ections } \\
0.026^{* *} \\
(0.006)\end{array}$ & $\begin{array}{l}0.034^{* *} \\
(0.006)\end{array}$ & $\begin{array}{l}0.038^{* *} \\
(0.007)\end{array}$ & $\begin{array}{l}0.049^{* *} \\
(0.010)\end{array}$ & $\begin{array}{l}0.032^{* *} \\
(0.009)\end{array}$ & $\begin{array}{l}0.050^{* *} \\
(0.010)\end{array}$ & $\begin{array}{l}0.055^{* *} \\
(0.011)\end{array}$ \\
\hline $\begin{array}{l}\times \text { init. div. } \\
\left(n_{i k}^{96} / n_{k}^{\max }\right) \\
\end{array}$ & $\begin{array}{c}-0.094^{* *} \\
(0.012) \\
\end{array}$ & $\begin{array}{c}-0.097^{* *} \\
(0.014) \\
\end{array}$ & $\begin{array}{c}-0.088^{* *} \\
(0.012) \\
\end{array}$ & $\begin{array}{c}-0.087^{* *} \\
(0.011) \\
\end{array}$ & $\begin{array}{c}-0.072^{* *} \\
(0.014) \\
\end{array}$ & $\begin{array}{c}-0.067^{* *} \\
(0.014) \\
\end{array}$ & $\begin{array}{c}-0.075^{* *} \\
(0.014) \\
\end{array}$ & $\begin{array}{c}-0.079^{* *} \\
(0.014) \\
\end{array}$ \\
\hline $\begin{array}{l}\text { Panel C: Years } \\
\text { train }_{i t} \text { (years) }\end{array}$ & $\begin{array}{c}\text { since first } \\
0.051^{* *} \\
(0.009)\end{array}$ & $\begin{array}{c}\text { connection } \\
0.036^{* *} \\
(0.008)\end{array}$ & $\begin{array}{l}0.049^{* *} \\
(0.009)\end{array}$ & $\begin{array}{l}0.056^{* *} \\
(0.010)\end{array}$ & $\begin{array}{l}0.071^{* *} \\
(0.014)\end{array}$ & $\begin{array}{l}0.044^{* *} \\
(0.013)\end{array}$ & $\begin{array}{l}0.072^{* *} \\
(0.015)\end{array}$ & $\begin{array}{l}0.080^{* *} \\
(0.015)\end{array}$ \\
\hline $\begin{array}{l}\times \text { init. div. } \\
\left(n_{i k}^{96} / n_{k}^{\max }\right)\end{array}$ & $\begin{array}{c}-0.142^{* *} \\
(0.019) \\
\end{array}$ & $\begin{array}{c}-0.145^{* *} \\
(0.021) \\
\end{array}$ & $\begin{array}{c}-0.132^{* *} \\
(0.018) \\
\end{array}$ & $\begin{array}{c}-0.131^{* *} \\
(0.018) \\
\end{array}$ & $\begin{array}{c}-0.105^{* *} \\
(0.021) \\
\end{array}$ & $\begin{array}{c}-0.098^{* *} \\
(0.022) \\
\end{array}$ & $\begin{array}{c}-0.110^{* *} \\
(0.021) \\
\end{array}$ & $\begin{array}{c}-0.117^{* *} \\
(0.021) \\
\end{array}$ \\
\hline Observations & 46,403 & 37,670 & 30,014 & 30,031 & 55,751 & 46,951 & 34,487 & 34,487 \\
\hline Clusters (it) & 598 & 506 & 368 & 368 & 598 & 506 & 368 & 368 \\
\hline
\end{tabular}

Note: Table shows coefficient estimates of the impact of direct BRI railway connections on the number of HS6 products exported within an HS2 sector. Samples distinguish countries included, where Treat+EU corresponds to the EU23 (i.e. EU25 minus Cyprus and Malta); Treat + NA corresponds to the 14 connected European countries as well as Canada and the US; and Treat + EA corresponds to the 14 connected European countries as well as Japan and South Korea. Results in columns (1) and (5) use the full sample, which includes the EU23 plus NA plus EA. All specifications include HS2 sector-year and HS2 sector-exporter fixed effects, and a control variable for total sectoral exports, $X_{i k t}$, as well as total number of goods exported. Standard errors in parentheses adjusted for clustering at exporter-year level. Statistical significance: $a=p<0.01,{ }^{* *}$ $\mathrm{p}<0.05,{ }^{*} \mathrm{p}<0.1$.

tive, given that the majority BRI connections via the Corridor concentrates in two countries. This could explain the relatively smaller coefficient estimates obtained for the purely European samples. However, we also noticed that there are potentially unobserved regional effects that drive our results (and inflate coefficient estimates for the non-European control groups). Although we control for countries' general export performance, there might be region-specific shocks that are correlated with exports to China and the gradual increase in the number of railway connections with Europe. To address the latter point we include a full set of region-year fixed effects into our model, where regions are the EU (i.e. the 23 European countries), East Asia (i.e. Japan and South Korea), and North America (i.e. Canada and the US).

In order to take into consideration also indirect access to the railway network we consider two modifications of our treatment group. First, we count countries as being connected to 
the BRI if they are either directly connected themselves or if a direct neighboring country gets connected. In our alternative modification, we use a wider criterion and include also countries that are less than $500 \mathrm{~km}$ away from a country that is directly connected. These modifications have a major impact on our treatment variable. For example, after the extension to direct neighbors, we count 11 instead of 2 countries (out of 23) with a connection since 2011. ${ }^{13}$ While the maximum number of connections a country obtained was 10 with our standard measure, taking into account indirect connections via neighbors or proximate countries enables some countries to access all 15 connections we consider in this paper.

Table 3: Export revenues due to direct or indirect railway connections to China

\begin{tabular}{|c|c|c|c|c|c|c|}
\hline \multirow[b]{2}{*}{ Measure BRI: } & (1) & $(2)$ & $(3)$ & (4) & $(5)$ & (6) \\
\hline & \multicolumn{2}{|c|}{$\begin{array}{l}\text { direct only } \\
\text { (baseline) }\end{array}$} & \multicolumn{2}{|c|}{$\begin{array}{l}\text { direct + indirect } \\
\text { (incl. neighbors) }\end{array}$} & \multicolumn{2}{|c|}{$\begin{array}{l}\text { direct }+ \text { indirect } \\
\text { (incl. proximate) }\end{array}$} \\
\hline \multicolumn{7}{|c|}{ Panel A: Export revenues } \\
\hline \multirow[t]{2}{*}{$\operatorname{train}_{i t}$ (binary) } & $0.091^{* *}$ & $-0.063^{*}$ & $0.146^{* *}$ & 0.021 & $0.172^{* *}$ & $0.109^{* *}$ \\
\hline & $026)$ & $(0.028)$ & $(0.024)$ & $(0.036)$ & $(0.024)$ & $(0.028)$ \\
\hline $\operatorname{train}_{i t}$ (count) & $\begin{array}{l}0.010^{* x} \\
(0.003)\end{array}$ & $\begin{array}{c}-0.011^{* 4} \\
(0.004)\end{array}$ & $\begin{array}{l}0.010^{* *} \\
(0.003)\end{array}$ & $\begin{array}{c}-0.014^{* 4} \\
(0.004)\end{array}$ & $\begin{array}{l}0.014^{* *} \\
(0.003)\end{array}$ & $\begin{array}{l}-0.006 \\
(0.005)\end{array}$ \\
\hline \multirow[t]{2}{*}{$\operatorname{train}_{i t}($ years) } & $0.016^{* *}$ & $-0.018^{* *}$ & $0.019^{* *}$ & $-0.026^{* *}$ & $0.027^{* *}$ & -0.002 \\
\hline & $(0.005)$ & $(0.006)$ & $(0.004)$ & $(0.007)$ & $(0.005)$ & $(0.009)$ \\
\hline \multicolumn{7}{|c|}{ Panel B: Exported HS6 products } \\
\hline \multirow[t]{2}{*}{$\operatorname{train}_{i t}$ (binary) } & $0.302^{* *}$ & $0.191^{* *}$ & $0.405^{* *}$ & $0.267^{* *}$ & $0.403^{* *}$ & $0.219^{* *}$ \\
\hline & $(0.038)$ & $(0.036)$ & $(0.028)$ & $(0.027)$ & $(0.028)$ & $(0.028)$ \\
\hline \multirow{2}{*}{$\operatorname{train}_{i t}$ (count) } & $0.049^{* *}$ & $0.036^{* *}$ & $0.048^{* *}$ & $0.034^{* *}$ & $0.047^{* *}$ & $0.029^{* *}$ \\
\hline & $(0.010)$ & $(0.009)$ & $(0.004)$ & $(0.004)$ & $(0.004)$ & $(0.004)$ \\
\hline \multirow[t]{2}{*}{$\operatorname{train}_{i t}$ (years) } & $0.071^{* *}$ & $0.049^{* *}$ & $0.082^{* *}$ & $0.058^{* *}$ & $0.081^{* *}$ & $0.046^{* *}$ \\
\hline & $(0.014)$ & $(0.013)$ & $(0.007)$ & $(0.007)$ & $(0.007)$ & $(0.008)$ \\
\hline Region-year FEs: & No & Yes & No & Yes & No & Yes \\
\hline Observations & 55,751 & 55,751 & 55,751 & 55,751 & 55,751 & 55,751 \\
\hline Clusters (it) & 598 & 598 & 598 & 598 & 598 & 598 \\
\hline
\end{tabular}

Note: Table shows PPML coefficient estimates of the impact of direct and indirect BRI railway connections on export revenues and the number of HS6 products exported within an HS2 sector. Each cell reports coefficient of a separate estimation. Samples include the full set of countries (i.e. the EU23 plus NA plus EA). All specifications include HS2 sector-year and HS2 sector-exporter fixed effects, and a control variable for total sectoral exports, $X_{i k t}$. Panel B also controls for total number of goods exported and differential effects of connection depending on countries' initial product coverage. Standard errors in parentheses adjusted for clustering at exporter-year level. Statistical significance: $\mathrm{a}=\mathrm{p}<0.01,{ }^{* *} \mathrm{p}<0.05,{ }^{*} \mathrm{p}<0.1$.

Results for export revenues. In Table 3, we report our PPML results for export revenues (in Panel A) and for export diversification (in Panel B). Looking first at Panel A,

\footnotetext{
${ }^{13}$ The extension to proximate countries adds one additional country to early treatment (i.e. the United Kingdom, which is $495 \mathrm{~km}$ away from Germany, according to the CEPII bilateral distances data set we used to construct our measure).
} 
we make two observations. Whenever we keep our original specification without region-year fixed effects, increasing the scope of our treatment group also increases the magnitude of the estimated coefficient for our BRI connections. This can be seen by comparing columns (1), (3), and (5) of Panel A and suggests that countries might export more to China, even if they are only indirectly connected via the Corridor.

However, we also observe that including region-year fixed effects results in substantial downward corrections of the coefficients. This implies that the observed increases of exports to China by newly connected countries are highly correlated with EU-wide changes in exports. Moreover, columns (2), (4) and (6) suggest that directly connected countries may have benefited less than indirectly connected countries from the new export opportunities via the Corridor. Taking into account also the indirectly connected countries, in column (6), we find that the existence of a connection to China via the Corridor is associated with about 11 percent higher exports to China. The number of connections as well as the number of years since a connection existed for the first time, does not appear to make any significant difference anymore.

Results for export diversification. Turning to Panel B of Table 3, we find a robust significantly positive relationship between railway connections and the range of products exported. Although region-year fixed effect induce downward corrections also here, we still find a relative increase in the number of products shipped by 20 percent on average. Every additional connection increases this range by about 3 percent and each additional year of operation corresponds to an about 5 percent increase in the product range.

Altogether, the results from this subsection support our hypothesis that the BRI has provided improved market access and new export opportunities for European countries. Countries with direct or indirect BRI connections appear to have about 10 percent higher export revenues from selling their goods to China. The fact that we cannot detect a robust relationship between export revenues and additional connections (or the time elapsed since their first setup) might be due to different factors we cannot observe in our data, such as differential frequency and capacity of utilization, potential time-lags, or network effects that prevent a clearer separation of connected an non-connected countries (or regions). We therefore attempt to augment our identification in the following subsection.

\subsection{Transport mode and differential responses across sectors}

Our main data set does not provide any information about the mode of transport chosen by exporters, which prevents us from verifying that the estimated changes in exports can actually be attributed to rail freight. Data from Eurostat, however, does provide such 
information for the years 2000-2019 for our set of European exporters. In this subsection, we leverage this information in order to further evaluate the contribution of the BRI to Europe's export performance.

\subsubsection{Rising importance of rail-freight?}

Data and measurement. Before presenting results, we have to discuss some features of the data. We work with a balanced panel of reported exports by each of our 23 European countries to China. The data is disaggregated at the HS2 sector level and distinguishes 9 modes of transport. Table 4 depicts these modes along with their number of non-zero observations, the number of HS2 sectors where they are used, and the percentage of the total shipping value they account for.

Table 4: Transport modes of European exports to China, 2000-2019

\begin{tabular}{lccccccccc}
\hline & $(1)$ & $(2)$ & $(3)$ & $(4)$ & $(5)$ & $(6)$ & $(7)$ & $(8)$ & $(9)$ \\
\cline { 2 - 9 } Transport mode & \multirow{2}{*}{ Sea } & \multirow{2}{*}{ Air } & \multirow{2}{*}{ Road } & Rail & \multirow{2}{*}{ Post } & $\begin{array}{c}\text { Inland } \\
\text { Waterw. }\end{array}$ & $\begin{array}{c}\text { Self } \\
\text { Prop. }\end{array}$ & $\begin{array}{c}\text { Fixed } \\
\text { Mech. }\end{array}$ & Unknown \\
\hline \# Non-zero Obs. & 27,876 & 29,395 & 20,383 & 5,605 & 4,825 & 931 & 290 & 94 & 2,764 \\
\# HS2 Sectors & 97 & 95 & 96 & 70 & 9 & 18 & 2 & 0 & 77 \\
\% of Exports & 60.5 & 30.1 & 2.9 & 1.5 & 0.1 & 0.1 & 4.0 & 0.0 & 0.9 \\
\hline
\end{tabular}

Note: Authors' calculations based on extraction from Eurostat data series (DS-043327) for 23 European countries and period 2000-2019. The total number of observations is 42,680 and the total number of nonzero observations in this data set is 33,696 . HS2 sectors were counted if transport mode accounted for at least 0.1 percent of the total value of sectoral shipments during the sample period.

Not surprisingly, sea transport accounts for the largest portion of shipments. It amounts to more than 60 percent of the total exported value and is used in all 97 HS2 sectors. ${ }^{14}$ Air transport accounts for 30 percent of the value of shipments, while only 1.5 percent of exports used rail freight. This minor number could be explained by the recency of the BRI connections, as the data already starts in 2000. However, another transport mode is surprisingly prominent. According to our calculations, about three percent of exports to China use road transport in a wide range of observations and sectors. ${ }^{15}$ Given this fairly unrealistic statistic, we consider the possibility that transport modes are not always accurately reported. The high number of observations with road transport might result from indirect shipments via export hubs in another country. Likewise, rail shipments might signify both, direct shipments to China or shipments to a seaport or other logistics hub.

\footnotetext{
${ }^{14}$ While HS chapter number 77 is not currently defined by the World Customs Organization (WCO), which administers the HS nomenclature, Eurostat reports trade in a residual chapter 99 for goods not else where classified.

${ }^{15}$ Another mode of transport worth explaining is "Self Propulsion", shown in column (7). Such trade takes place essentially only in two sectors, which are "air planes" (HS chapter 88) and "ships" (HS chapter 89).
} 
Following this reasoning we consider changes in the transport mode structure for countries with a direct rail connection to China via the Corridor. To assess this, we use the varying indicators for a direct connection, namely: (i) a simple dummy for a connection; (ii) the number of different connections; and (iii) the years since the first direct connection was set up. As dependent variables, we use different measures for the prominence of rail transport. First, similar to Hummels and Schaur (2013) we use the log-ratios of exports via rail to non-rail transport modes. Since such a specification has the advantage that values have no upper or lower bound, a drawback in the context of our data is a relatively small number of observations, due to frequent zeros. Hence, we also estimate the fraction of rail exports in total shipments using PPML.

Table 5: Railways as transport mode for European exports to China

\begin{tabular}{|c|c|c|c|c|c|c|}
\hline & (1) & $(2)$ & $(3)$ & $(4)$ & $(5)$ & $(6)$ \\
\hline Estimation method & \multicolumn{5}{|c|}{ Least Squares (OLS) } & PPML \\
\hline Dep. var. & $\ln \frac{X_{i k t}^{\text {rail }}}{X_{i k t}^{\text {sea }}}$ & $\ln \frac{X_{i k t}^{\text {rail }}}{X_{i k t}^{\text {air }}}$ & $\ln \frac{X_{i k t}^{\mathrm{rail}}}{X_{i k t}^{\mathrm{air}+\mathrm{sea}}}$ & $\ln \frac{X_{i k t}^{\text {rail }}}{X_{i k t}^{\text {non-rail }}}$ & $\ln \frac{X_{i k t}^{\text {rail }}}{X_{i k t}}$ & $\frac{X_{i k t}^{\text {rail }}}{X_{i k t}}$ \\
\hline $\begin{array}{l}\text { Panel A: Binary in } \\
\operatorname{train}_{i t} \text { (binary) }\end{array}$ & $\begin{array}{c}\text { licator }(\mathrm{c} \\
0.287 \\
(0.271)\end{array}$ & $\begin{array}{c}\text { onnected } \\
0.154 \\
(0.288)\end{array}$ & $\begin{aligned}= & 1) \\
& 0.155 \\
& (0.297)\end{aligned}$ & $\begin{array}{c}0.157 \\
(0.278)\end{array}$ & $\begin{array}{c}0.159 \\
(0.271)\end{array}$ & $\begin{array}{r}-0.722^{* *} \\
(0.243)\end{array}$ \\
\hline $\begin{array}{l}\text { Panel B: Count ir } \\
\text { train }_{i t} \text { (count) }\end{array}$ & $\begin{array}{c}\text { icator (\# } \\
0.299^{* *} \\
(0.065)\end{array}$ & $\begin{array}{l}\text { of direct } \\
0.318^{* *} \\
(0.065)\end{array}$ & $\begin{array}{c}\text { connectio } \\
0.268^{* *} \\
(0.072)\end{array}$ & $\begin{array}{l}\text { s) } \\
0.278^{* *} \\
(0.066)\end{array}$ & $\begin{array}{l}0.284^{* *} \\
(0.065)\end{array}$ & $\begin{array}{l}0.184^{* *} \\
(0.071)\end{array}$ \\
\hline $\begin{array}{l}\text { Panel C: Duration } \\
\text { train }_{i t} \text { (years) }\end{array}$ & $\begin{array}{c}\text { ndicator } \\
0.500^{* *} \\
(0.104)\end{array}$ & $\begin{array}{c}\text { (years sir } \\
0.524^{* *} \\
(0.102)\end{array}$ & $\begin{array}{c}\text { ce first di } \\
0.480^{* *} \\
(0.107)\end{array}$ & $\begin{array}{c}\text { ct connect } \\
0.469^{* *} \\
(0.103)\end{array}$ & $\begin{array}{l}\text { n) } \\
0.477^{* *} \\
(0.101)\end{array}$ & $\begin{array}{l}0.561^{* *} \\
(0.084)\end{array}$ \\
\hline $\begin{array}{l}\text { Observations } \\
\text { Clusters }(i t)\end{array}$ & $\begin{array}{c}4,316 \\
316\end{array}$ & $\begin{array}{c}4,795 \\
329\end{array}$ & $\begin{array}{c}4,878 \\
333\end{array}$ & $\begin{array}{c}4,939 \\
333\end{array}$ & $\begin{array}{c}4,972 \\
333\end{array}$ & $\begin{array}{c}16,473 \\
424\end{array}$ \\
\hline
\end{tabular}

Note: Table shows log-linear regression and PPML coefficient estimates for prevalence of rail transport among European exports to China, conditional on direct rail connection via BRI. Each cell reports coefficient of a separate estimation. Sample represents 23 EU countries, 97 HS2 sectors, and 20 years (2000-2019). All specifications include HS2 sector-year and HS2 sector-exporter fixed effects, as well as exporter-specific linear trends. Standard errors in parentheses adjusted for clustering at exporter-year level. Statistical significance: $\mathrm{a}=\mathrm{p}<0.01,{ }^{* *} \mathrm{p}<0.05,{ }^{*} \mathrm{p}<0.1$.

Results. We show our results in Table 5, where all specifications include HS2 sector-year and HS2 sector-exporter fixed effects (as in previous specifications), as well as exporterspecific linear trends. Using the simple binary indicator for a direct connection does not produce any clear results (Panel A). The log-linear specifications report positive, yet sta- 
tistically insignificant coefficients, regardless of how railway prominence is measured. Our PPML specification in column (6) reports even a negative and significant coefficient, which suggests that rail exports became less prominent. This is an implausible result and suggests that simply observing the pure existence of a rail connection is not sufficient to determine the use of rail transportation to China.

We obtain more consistent findings as we use finer measures for direct connections. In Panel B, we observe that each additional direct rail connection to China increases rail-freight relative to sea or air freight by about thirty percent. Similar magnitudes are reported for rail-freight relative to other non-rail (or overall) exports. The PPML estimator makes a downward correction of these coefficients to about 18 percent. Similarly, in Panel C, we observe that each additional year since the first launch of a direct rail connection to China is associated with higher utilization of this transport mode.

Overall, we find that direct BRI connections appear to be associated with the mode of transport European exporters choose. Not surprisingly, the age and number of these train connections matter for this decision, as we do not distinguish their quality, capacity and frequency of operations.

\subsubsection{Heterogeneous responses across industries}

Besides the general relationship assessed in the previous subsection, it is also of interest to understand which industries in particular switch to increased rail-freight. Given that products can be expected to differ in their propensity to use a particular transport mode, we can use such variation also to revisit our general results on the value and diversification of exports to China.

We therefore estimate once again our specifications from above, but this time separately for each HS2 sector. The log-linear model from Table 5 column (5) now takes the following form:

$$
(\log ) \text { Rail share }:=\ln \frac{X_{i t}^{R, k}}{X_{i t}^{k}}=\beta^{k} \operatorname{train}_{i t}^{\mathrm{yrs}}+\sum_{i} \delta_{i}^{k}\left(\mathbf{D}_{i} \times y e a r_{t}\right)+\varepsilon_{i t}^{k}
$$

where $\operatorname{train}_{i t}^{\mathrm{yrs}}$ measures the number of years elapsed since setup of the first direct connection and $\sum_{i} \delta_{i}^{k}\left(\mathbf{D}_{i} \times\right.$ year $\left._{t}\right)$ denotes exporter-specific linear trends to proxy general gradual

preference shifts over time. Our interest focuses on the estimated $\hat{\beta}^{k}$, which indicates the relative probability of HS2 sector- $k$ to shift towards rail freight, as direct connections to China via the Corridor are being launched.

To analyze our estimation results, we note that our specification is very similar to the one used by Hummels and Schaur (2013), who estimate sector-specific time-sensitivity parameters in a transport-mode choice model for air-freight versus container shipments. We 
can compare our results to see how the differential response across sectors in switching to increased rail-freight relates to their estimates of products' time-sensitivity. ${ }^{16}$ We expect that rail-transport is most likely to be adopted at intermediate levels of time-sensitivity, as it is faster than sea transport but still considerably slower than air-freight.

Our results are plotted in Figure 3 (a)-(f), where we removed extreme values of timesensitivity and $\hat{\beta}^{k}{ }^{17}$ Despite large confidence intervals, we find patterns that resemble a non-linear inversely u-shaped relationship with time sensitivity in most of our specifications. Only our PPML model seems to reject a clear non-monotonic relationship, and instead suggests that time sensitivity is orthogonal to the relative sectoral propensity of shifting towards rail-transport. Such lack of a clear relationship could point at additional factors being at play for the transport-mode choice of exporters. However, given the limited number of observations in this figure (as well as the underlying data samples), the presented patterns can be seen to be only of indicative nature.

\subsubsection{Revisiting the BRI effect on European exports}

In this final subsection, we use our estimates of $\beta^{k}$ to provide further evidence on the relationship between the BRI railways and European exports to China. With six different sets of $\beta^{k}$ estimates (each based on a different specification, as presented above), we expect that exports increase more in sectors where $\beta^{k}>0$ and significant. Hence, using a significance threshold of 10 percent, we create an HS2-specific and time-invariant variable, which is equal to the estimated $\hat{\beta}^{k}$, if the above requirement holds, while it takes a value of 0 in all other cases. When carrying out our estimation, we benefit from an additional sectoral dimension in our BRI measure, which allows us to control for exporter-specific aggregate supply shocks using a full set of exporter-year fixed effects. This is an improvement compared to our previous approach, where the lack of cross-sectoral variation allowed identification exclusively across countries and over time. Hence, Table 6 reports results only for the differential correlation between BRI connections and exports that is conditional on the responsiveness of HS2 sectors in their transport mode.

Panel A of Table 6 shows that we continue to obtain a positive and statistically significant relationship between export revenues and the existence of railway connections to China.

\footnotetext{
${ }^{16}$ Time-sensitivity in their paper is defined as the ad-valorem tariff equivalent of importers' willingness to pay for a one day earlier delivery of a product. Hence, a higher willingness to pay indicates higher time-sensitivity.

${ }^{17}$ We define outliers as observations with a value residing outside the upper and lower quartile of the distribution by more than twice the inter-quartile range. While the number of outliers is small they are typically extreme and often resulted from a small number of observations in the original estimation sample. We removed them here mainly for the purposes of illustration, while they do not significantly affect our conclusions.
} 
Figure 3: Estimated increase in rail-transport due to BRI versus time-sensitivity, by HS2 sector

(a) $(\log )$ rail over sea

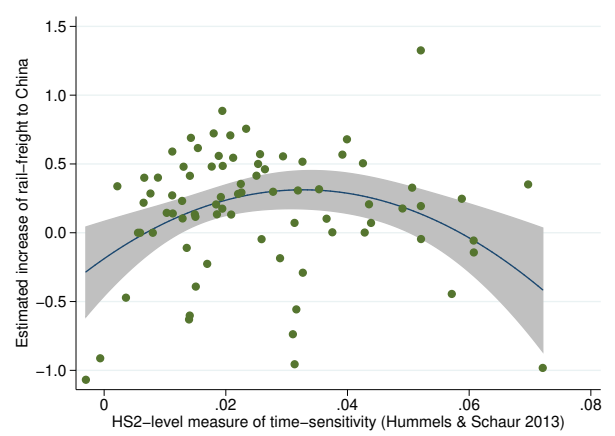

(c) $(\log )$ rail over air+sea

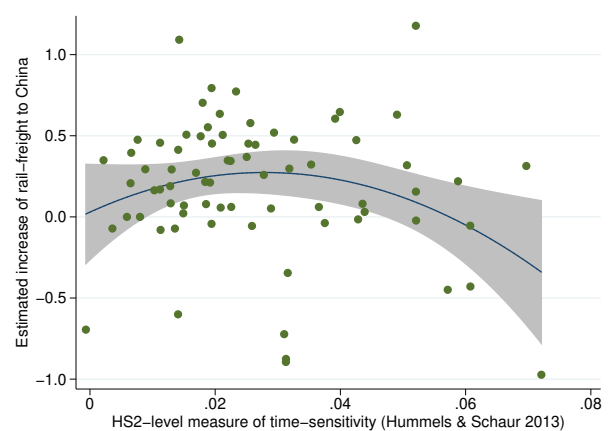

(e) $(\log )$ rail share

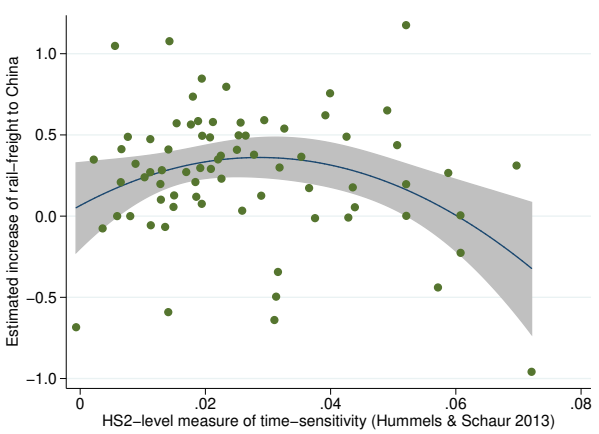

(b) $(\log )$ rail over air

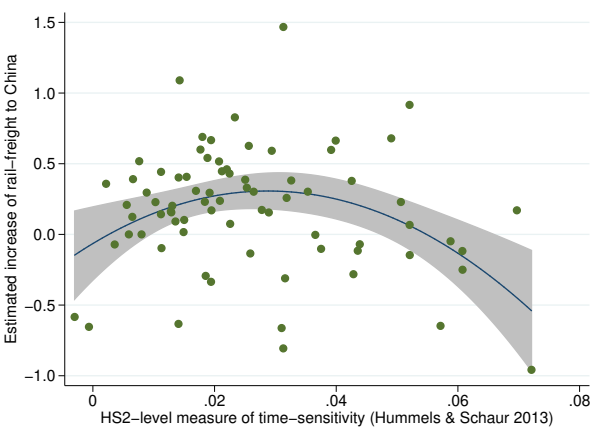

(d) (log) rail over non-rail

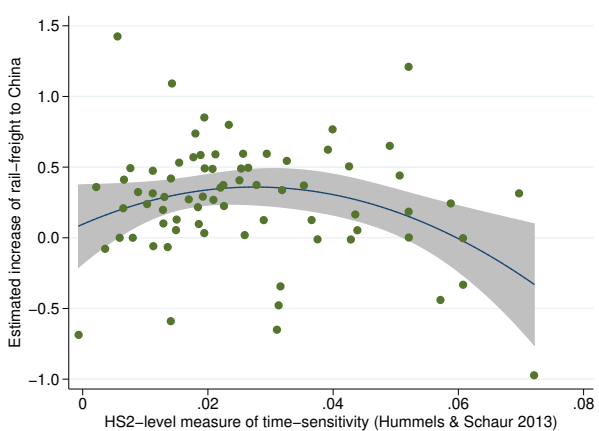

(f) rail share (PPML)

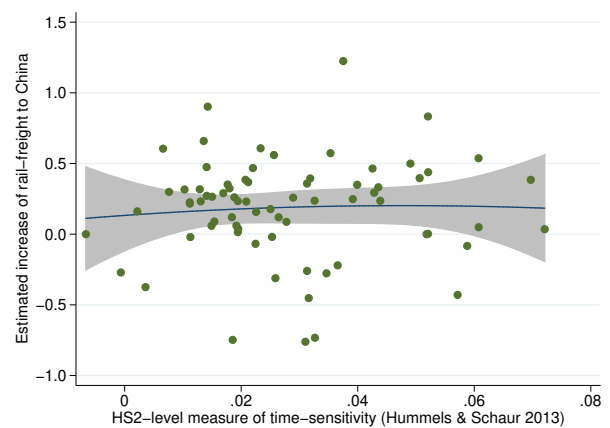

Note: Figures depict estimated responses of exports from Europe to China via rail-freight (using different measures, see subtitles) and their relationship with a sectoral measure of time-sensitivity according to Hummels and Schaur (2013). All estimates, except the one displayed in panel (f), are based on a log-linear specification displayed in Eq. (4). 
Table 6: Export revenues and diversification revisited

\begin{tabular}{|c|c|c|c|c|c|c|}
\hline \multirow{3}{*}{$\begin{array}{l}\text { Estimation method } \\
\hat{\beta}^{k} \text {-specification }(s)\end{array}$} & $(1)$ & $(2)$ & $(3)$ & $(4)$ & $(5)$ & $(6)$ \\
\hline & \multicolumn{5}{|c|}{ Least Squares (log-linear) } & PPML \\
\hline & $\begin{array}{l}\text { Rail } \\
\text { over } \\
\text { Sea }\end{array}$ & $\begin{array}{c}\text { Rail } \\
\text { over } \\
\text { Air }\end{array}$ & $\begin{array}{c}\text { Rail } \\
\text { over } \\
\text { Air+Sea }\end{array}$ & $\begin{array}{c}\text { Rail } \\
\text { over } \\
\text { Non-rail }\end{array}$ & $\begin{array}{c}\text { Rail } \\
\text { over } \\
\text { Total }\end{array}$ & $\begin{array}{c}\text { Rail } \\
\text { over } \\
\text { Total } \\
\end{array}$ \\
\hline $\begin{array}{l}\text { Panel A: Dependen } \\
\text { train }_{i t}^{\text {prox. }} \times \tilde{\beta}^{k, s}\end{array}$ & $\begin{array}{l}\text { variable } \\
0.270^{* *} \\
(0.069)\end{array}$ & $\begin{array}{c}\text { export re } \\
0.291^{* *} \\
(0.071)\end{array}$ & $\begin{array}{l}\text { enues } \\
0.295^{* *} \\
(0.069)\end{array}$ & $\begin{array}{l}0.303^{* *} \\
(0.067)\end{array}$ & $\begin{array}{l}0.308^{* *} \\
(0.069)\end{array}$ & $\begin{array}{l}0.195^{*} \\
(0.087)\end{array}$ \\
\hline Implied change $(\%)$ & +4.8 & +4.4 & +5.0 & +5.7 & +6.0 & +4.2 \\
\hline $\begin{array}{l}\text { Panel B: Dependen } \\
\text { train }_{i t}^{\text {prox. }} \times \tilde{\beta}^{k, s}\end{array}$ & $\begin{array}{l}\text { variable } \\
0.222^{* *} \\
(0.033)\end{array}$ & $\begin{array}{c}\text { Number I } \\
0.171^{* *} \\
(0.030)\end{array}$ & $\begin{array}{l}\text { S6 produc } \\
0.232^{* *} \\
(0.033)\end{array}$ & $\begin{array}{l}\text { S shipped } \\
0.248^{* *} \\
(0.034)\end{array}$ & $\begin{array}{l}0.253^{* *} \\
(0.035)\end{array}$ & $\begin{array}{l}-0.027^{a} \\
(0.016)\end{array}$ \\
\hline Implied change (\%) & +4.0 & +2.6 & +4.0 & +4.7 & +4.9 & -0.6 \\
\hline $\begin{array}{l}\# \operatorname{HS} 2\left(\tilde{\beta}^{k, s}>0\right) \\
\text { Average }\left(\tilde{\beta}^{k, s}\right)\end{array}$ & $\begin{array}{c}28 \\
0.18\end{array}$ & $\begin{array}{c}23 \\
0.15\end{array}$ & $\begin{array}{c}27 \\
0.17\end{array}$ & $\begin{array}{c}29 \\
0.19\end{array}$ & $\begin{array}{c}31 \\
0.2\end{array}$ & $\begin{array}{c}37 \\
0.22\end{array}$ \\
\hline $\begin{array}{l}\text { Observations } \\
\text { Clusters }(i t)\end{array}$ & $\begin{array}{c}46,403 \\
598\end{array}$ & $\begin{array}{c}46,403 \\
598\end{array}$ & $\begin{array}{c}46,403 \\
598\end{array}$ & $\begin{array}{c}46,403 \\
598\end{array}$ & $\begin{array}{c}46,403 \\
598\end{array}$ & $\begin{array}{c}55,751 \\
598\end{array}$ \\
\hline
\end{tabular}

Note: Table shows log-linear regression and PPML coefficient estimates for value EU exports to China (Panel A) and number of HS6 products shipped (Panel B), conditional of direct or indirect rail connection (via proximate countries) and sectors' relative probability to use rail-freight (i.e., $\tilde{\beta}^{k, s}$, estimated as indicated in column title). All specifications include HS2 sector-year and HS2 sector-exporter, and exporter-year fixed effects, as well as aggregate HS2-level exports to the rest of the world (and overall diversification by sector, in Panel B). Standard errors in parentheses adjusted for clustering at exporter-year level. Statistical significance: $\mathrm{a}=\mathrm{p}<0.01,{ }^{* *} \mathrm{p}<0.05,{ }^{*} \mathrm{p}<0.1$. Numbers displayed below coefficients and standard errors indicate implied percentage change in exports. Numbers displayed in the first two rows at the bottom of the table indicate number (i) of HS2 sectors that were estimated to increase utilization of rail-freight, and (ii) average $\tilde{\beta}$ observed in estimation sample.

As previously, log-linear specifications seem to produce somewhat larger coefficients. ${ }^{18}$ Nevertheless, we find that the implied percentage change in export revenues is fairly similar, ranging from 4.2-6.0 percent, depending on the specification. ${ }^{19}$ While this is less than the estimated 11 percent increase in revenues we obtained earlier in Table 3 column (6), we conclude that BRI railway connections are likely to have increased EU export revenues in a range of different sectors. In Panel B, we report our corresponding results for export diversification and find again that the number of goods exported to China increased in particular sectors and relative to non-connected countries by about 4 percent on average.

\footnotetext{
${ }^{18}$ We use log-linear specifications here to remain consistent with the method from which we obtained our estimates of $\hat{\beta}^{k, s}$

${ }^{19}$ We obtain implied changes by multiplying the estimated coefficient with the average value of $\tilde{\beta}^{k, s}$ in our sample, and multiplying with 100 to obtain percentage units.
} 
Our PPML estimate in columns (6) reports a quantitatively small negative coefficient, which is marginally significant. While this may cast some doubts about the robustness our results, we note that this sample also encompasses the largest number of sectors that are considered to shift towards rail transport. Over-estimating the number of responsive sectors here might explain weaker estimated responses in diversification, due to measurement error.

\section{Conclusion}

Our paper studies patterns in merchandise trade data of European countries exporting to China, conditional on the existence of new transport routes via the BRI railway Corridor. We exploit detailed information on the starting date and number of such connections and leverage their variation across countries and over time to analyze changes in the value of shipments and the range of different products exported. Using alternative measures, estimation methods and model specifications, we find strong support for a positive relationship between BRI connections and export performance, which suggest that the new railway connections have contributed to lower trade barriers and improved market access opportunities.

Our baseline results suggest an about 10 percent increase in export revenues, which are realized not only by directly connected countries, but also by other proximately-located European exporters, while being distinct from Europe-wide changes in export activity with China. Using additional information on transport-mode choices, we further find that direct BRI connections are positively correlated with increased utilization of rail-freight for exports to China. Sectors (defined at the HS2 Chapter level) where rail-transport is estimated to increase the most appear to (i) be of intermediate time-sensitivity and (ii) drive at least half of the estimated increase in overall exports to China. While the former finding is in line with theoretical considerations that rail-freight has intermediate time-saving potential when compared to slow ocean cargo and very fast air-freight, the latter findings lend support to our measurement and identification strategy which faces the limitation of not directly observing a number of potential qualitative features of the individual BRI railway connections.

To this end, our study is the first to present empirical evidence on the efficiency of the BRI and its potential benefits for European exporters. These benefits appear to materialize in different dimensions, but are quantitatively still limited due to their only recent activation in many cases. Nevertheless, we cannot reject trade-creation effects through easier market access and find that our estimates are very similar to findings obtained by Baniya et al. (2019) from structural estimates. While their results are not directly comparable to ours (they focus on trade among all countries connected via the BRI, except Europe), their preferred estimate of a 4.2 percent increase corresponds to the lower bound reported in our findings. This might 
be plausible, given that trade effects of the BRI are determined also by other factors, such as the type of goods traded or complementary trade agreements.

To conclude, more detailed information about the differential characteristics of the railway connections (e.g. frequency, capacity utilization, etc.) will be useful for future analyses which will be able to exploit also additional years of data. With additional information at hand, it might also be possible to test through which of the different theoretical channels, the BRI connections affect trade activity, as they may operate through changes in travelled distances, transit times, and transportation cost.

\section{References}

Baniya, S., Rocha Gaffurri, N. P., and Ruta, M. (2019). Trade Effects of the New Silk Road: A Gravity Analysis. Policy Research working paper 8694, World Bank Group.

Bertoli, S., Goujon, M., and Santoni, O. (2016). The CERDI-seadistance database. Working Papers 201607, CERDI.

Bougheas, S., Demetriades, P. O., and Morgenroth, E. L. W. (1999). Infrastructure, transport costs and trade. Journal of International Economics, 47(1):169-189.

Cai, P. (2017). Understanding China's Belt and Road Initiative. Sydney: Lowy Institute for International Policy.

Chaney, T. (2018). The gravity equation in international trade: An explanation. Journal of Political Economy, 126(1):150-177.

Chhetri, P., Nkhoma, M., Peszynski, K., Chhetri, A., and Lee, P. T.-W. (2018). Global logistics city concept: a cluster-led strategy under the belt and road initiative. Maritime Policy \& Management, 45(3):319-335.

Ciani, A. and Mau, K. (2020). When Time Matters: Eastern Europe's Response to Chinese Competition. Research Memorandum 007, Maastricht University, Graduate School of Business and Economics (GSBE).

Djankov, S., Freund, C., and Pham, C. S. (2010). Trading on time. The Review of Economics and Statistics, 92(1):166-173.

Donaldson, D. (2018). Railroads of the raj: Estimating the impact of transportation infrastructure. American Economic Review, 108(4-5):899-934. 
Donaldson, D. and Hornbeck, R. (2016). Railroads and American Economic Growth: A "Market Access" Approach *. The Quarterly Journal of Economics, 131(2):799-858.

Egger, P. and Larch, M. (2017). The Bilateral and Multilateral Trade Effects of Road and Railway Transport Infrastructure. mimeo, Ifo Institute for Economic Research and CESifo.

Enderwick, P. (2018). The economic growth and development effects of china's one belt, one road initiative. Strategic Change, 27(5):447-454.

Gaulier, G. and Zignago, S. (2010). BACI: International Trade Database at the Product Level: The 1994-2007 Version. CEPII Working Paper 2010-23, CEPII.

Head, K. and Mayer, T. (2014). Chapter 3 - gravity equations: Workhorse,toolkit, and cookbook. In Gopinath, G., Helpman, E., and Rogoff, K., editors, Handbook of International Economics, volume 4 of Handbook of International Economics, pages 131 - 195. Elsevier.

Hummels, D. (2007). Transportation Costs and International Trade in the Second Era of Globalization. Journal of Economic Perspectives, 21(3):131-154.

Hummels, D. and Skiba, A. (2004). Shipping the Good Apples Out? An Empirical Confirmation of the Alchian-Allen Conjecture. Journal of Political Economy, 112(6):1384-1402.

Hummels, D. L. and Schaur, G. (2013). Time as a Trade Barrier. American Economic Review, 103(7):2935-2959.

Jackson, K. and Shepotylo, O. (2018). 'Belt and Road': The 'China Dream'? mimeo, SSRN repository.

Lau, Y., Tam, K., Ng, A. K. Y., Fu, X., Jing, Z., and Feng, J. (2018). Effects of the 'belt and road' initiative on the wine import logistics of china. Maritime Policy $\mathcal{E} 3$ Management, 45(3):403-417.

Lee, P. T.-W., Hu, Z.-H., Lee, S.-J., Choi, K.-S., and Shin, S.-H. (2018). Research trends and agenda on the belt and road (b\&r) initiative with a focus on maritime transport. Maritime Policy \& Management, 45(3):282-300.

Li, Y., Bolton, K., and Westphal, T. (2018). The effect of the New Silk Road railways on aggregate trade volumes between China and Europe. Journal of Chinese Economic and Business Studies, 16(3):275-292.

Li, Y. and Schmerer, H.-J. (2017). Trade and the New Silk Road: opportunities, challenges, and solutions. Journal of Chinese Economic and Business Studies, 15(3):205-213. 
Limão, N. and Venables, A. J. (2001). Infrastructure, geographical disadvantage, transport costs, and trade. The World Bank Economic Review, 15(3):451-479.

Liu, X., Zhang, K., Chen, B., Zhou, J., and Miao, L. (2018). Analysis of logistics service supply chain for the One Belt and One Road initiative of China. Transportation Research Part E: Logistics and Transportation Review, 117(C):23-39.

McKinsey (2016). China's one belt, one road: will it reshape global trade? Featured insights, McKinsey \& Company.

Ruta, M., Freund, C., and Foster, A. (2020). The Economics of the Belt and Road Initiative, volume (forthcoming) of Journal of Development Economics. Special Issue.

Santos-Silva, J. M. C. and Tenreyro, S. (2006). The Log of Gravity. The Review of Economics and Statistics, 88(4):641-658.

Shao, Z.-Z., Ma, Z.-J., Sheu, J.-B., and Gao, H. O. (2018). Evaluation of large-scale transnational high-speed railway construction priority in the belt and road region. Transportation Research Part E: Logistics and Transportation Review, 117(C):40-57.

Waugh, M. E. (2010). International Trade and Income Differences. American Economic Review, 100(5):2093-2124.

World Bank, T. (2017). Belt and Road Economics : Opportunities and Risks of Transport Corridors. Washington, DC: World Bank.

Yang, D., Jiang, L., and Ng, A. K. (2018). One belt one road, but several routes: A case study of new emerging trade corridors connecting the far east to europe. Transportation Research Part A: Policy and Practice, 117:190 - 204.

Zhang, L., Luo, M., Yang, D., and Li, K. (2018). Impacts of trade liberalization on chinese economy with belt and road initiative. Maritime Policy \& Management, 45(3):301-318. 


\section{Appendix}

\section{A Additional material}

Table A1: Chinese BRI investment projects since October 2013

\begin{tabular}{lccccc}
\hline & $(1)$ & $(2)$ & $(3)$ & $(4)$ & $(5)$ \\
\cline { 2 - 6 } Region & $\begin{array}{c}\text { \# countries } \\
\text { involved }\end{array}$ & $\begin{array}{c}\text { \# BRI } \\
\text { projects }\end{array}$ & $\begin{array}{c}\text { share of all } \\
\text { Chinese } \\
\text { projects } \\
\text { in region }\end{array}$ & $\begin{array}{c}\text { share of } \\
\text { total } \\
\text { Chinese } \\
\text { inv. volume } \\
\text { in region }\end{array}$ & $\begin{array}{c}\text { share of } \\
\text { total } \\
\text { Chin. BRI } \\
\text { inv. volume }\end{array}$ \\
\hline East Asia & 16 & 363 & 0.99 & 0.99 & 0.29 \\
Sub-Saharan Africa & 31 & 314 & 0.93 & 0.94 & 0.24 \\
West Asia & 16 & 259 & 0.85 & 0.91 & 0.21 \\
Middle East + N. Africa & 13 & 194 & 1.00 & 1.00 & 0.09 \\
Europe & 22 & 127 & 0.34 & 0.22 & 0.11 \\
Americas & 12 & 76 & 0.48 & 0.49 & 0.04 \\
Japan + South Korea & 1 & 14 & 0.50 & 0.54 & 0.00 \\
Australia + N. Zealand & 1 & 8 & 0.06 & 0.05 & 0.00 \\
Canada + United States & 0 & 0 & 0.00 & 0.00 & 0.00 \\
\hline Total & 112 & 1,355 & 0.63 & 0.69 & 1.00 \\
\hline
\end{tabular}

Note: Authors' calculations based on monthly CGIT data, spanning the period from October 2013 through December 2019. The original data set reports a total of 2,137 investment projects during this period. Column (1) displays the number of countries in a region that receive Chinese BRI-related investment, while column (2) counts the number of transaction in a region. Column (3) indicates how large then number of BRI projects is compared to the total number of Chinese investment projects in the region. Column (4) shows the same ratio, but for respective transaction volumes, measured originally in million USD. Column (5) divides a region's total BRI investment volume by China's global BRI-related foreign investment. 
Table A2: Summary of cargo railway connections between China and the EU

\begin{tabular}{|c|c|c|c|c|c|c|}
\hline $\begin{array}{l}\text { Name of } \\
\text { connection }\end{array}$ & $\begin{array}{l}\text { Start/End } \\
\text { China }\end{array}$ & $\begin{array}{l}\text { Start/End } \\
\text { Europe }\end{array}$ & $\begin{array}{l}\text { Operating } \\
\text { since }\end{array}$ & $\begin{array}{l}\text { Distance } \\
(\mathrm{km})\end{array}$ & $\begin{array}{l}\text { Duration } \\
\text { (days) }\end{array}$ & $\begin{array}{c}\text { Duration } \\
\text { sea } \\
\text { (days) }\end{array}$ \\
\hline \multirow[t]{3}{*}{$\mathrm{YuXinOu}$} & \multirow[t]{3}{*}{ Chongqing } & Duisburg, DEU & 01-2011 & 11,179 & 14 & 35 \\
\hline & & Malaszewice, POL & 01-2011 & 10,000 & 11 & 40 \\
\hline & & Mannheim, DEU & $11-2018$ & 11,200 & 17 & 35 \\
\hline SuManOu & Suzhou & Warsaw, POL & 11-2012 & 11,200 & 15 & \\
\hline \multirow[t]{9}{*}{ RongXinOu } & \multirow[t]{9}{*}{ Chengdu } & Lodz, POL & 04-2013 & 9,826 & 11 & 27 \\
\hline & & Nuremberg, DEU & $10-2015$ & 10,500 & 13 & 40 \\
\hline & & Tilburg, NED & $10-2016$ & 10,947 & 15 & 45 \\
\hline & & Prague, CZE & $10-2017$ & 10,200 & 13 & 35 \\
\hline & & Milan, ITA & $11-2017$ & 11,694 & 14 & \\
\hline & & Rotterdam, NED & $10-2017$ & 11,100 & 15 & \\
\hline & & Vienna, AUT & 04-2018 & 9,800 & 13 & 40 \\
\hline & & Luxembourg, BLX & 04-2019 & 10,000 & 14 & \\
\hline & & Budapest, HUN & 08-2019 & & 15 & \\
\hline \multirow[t]{6}{*}{ ZhengOu } & \multirow[t]{6}{*}{ Zhengzhou } & Hamburg, DEU & 07-2013 & 10,214 & 15 & \\
\hline & & Duisburg, DEU & $07-2013$ & 10,400 & 15 & \\
\hline & & Warsaw, POL & 07-2013 & 9,400 & 13 & \\
\hline & & Munich, DEU & 08-2017 & & 15 & \\
\hline & & Zaragoza, ESP & $12-2017$ & & 26 & 55 \\
\hline & & Liege, BLX & $10-2018$ & 10,650 & 15 & \\
\hline \multirow[t]{5}{*}{ HanXinOu } & \multirow[t]{5}{*}{ Wuhan } & Duisburg, DEU & 04-2014 & 10,863 & 16 & \\
\hline & & Malaszewice, POL & 04-2014 & 9,600 & 13 & \\
\hline & & Hamburg, DEU & 04-2014 & 10,650 & 16 & \\
\hline & & Lyon, FRA & $04-2016$ & 11,300 & 16 & 55 \\
\hline & & Amsterdam, NED & 05-2019 & 11,000 & 15 & \\
\hline \multirow[t]{5}{*}{ XiangOu } & \multirow[t]{5}{*}{ Changsha } & Duisburg, DEU & $10-2014$ & 11,803 & 15 & \\
\hline & & Warsaw, POL & $10-2014$ & 10,700 & 13 & \\
\hline & & Budapest, FRA & 06-2017 & 10,118 & 15 & \\
\hline & & Hamburg, DEU & $11-2017$ & 11,500 & 15 & \\
\hline & & Tilburg, NED & 08-2018 & 12,912 & 15 & \\
\hline \multirow[t]{8}{*}{ YiXinOu } & \multirow[t]{8}{*}{ Yiwu } & Madrid, ESP & $11-2014$ & 13,052 & 21 & \\
\hline & & Malaszewice, POL & $11-2014$ & 10,000 & 11 & \\
\hline & & Duisburg, DEU & $11-2014$ & 11,200 & 13 & \\
\hline & & Riga, LVA & $10-2016$ & 11,066 & 15 & \\
\hline & & London, GBR & 01-2017 & 12,000 & 18 & \\
\hline & & Prague, CZE & 09-2017 & 10,500 & 16 & \\
\hline & & Amsterdam, NED & 03-2018 & 11,500 & 16 & \\
\hline & & Zaragoza, ESP & $11-2018$ & 12,300 & 19 & \\
\hline \multirow[t]{3}{*}{$\mathrm{HeXinOu}$} & \multirow[t]{3}{*}{ Hefei } & Hamburg, DEU & $06-2015$ & 10,600 & 15 & \\
\hline & & Malaszewice, POL & 06-2015 & 9,550 & 13 & \\
\hline & & Vuosaari, FIN & $12-2018$ & & 16 & \\
\hline \multirow[t]{2}{*}{$\mathrm{HaOu}$} & Harbin & Hamburg, DEU & 06-2015 & 9,820 & 16 & \\
\hline & & Malaszewice, POL & 06-2015 & 8,320 & 14 & \\
\hline Changanhoa & Xian & Duisburg, DEU & $10-2016$ & 9,700 & 16 & \\
\hline & & Hamburg, DEU & $10-2016$ & 9,400 & 16 & \\
\hline & & Kouvala, FIN & $11-2017$ & 8,000 & 12 & \\
\hline & & Budapest, HUN & $04-2017$ & 9,300 & 17 & 47 \\
\hline & & Riga, LVA & $11-2018$ & 11,066 & 12 & \\
\hline & & Prague, CZE & 03-2019 & 9,623 & 11 & \\
\hline & & Mannheim, DEU & 05-2019 & & 15 & \\
\hline & & Milan, ITA & 07-2019 & & 18 & \\
\hline & & Verona, ITA & 08-2019 & & 15 & \\
\hline & & Bratislava, SKA & $10-2019$ & & 12 & \\
\hline & & Gdansk, POL & $11-2019$ & 9,000 & 12 & \\
\hline - & Dalian & Bratislava, SKA & $10-2017$ & 10,537 & 15 & \\
\hline- & Urumqi & Riga, LVA & $10-2017$ & & 18 & \\
\hline- & Xiamen & Budapest, HUN & 01-2018 & 11,595 & 18 & \\
\hline- & Ganzhou & Warsaw, POL & $08-2017$ & & 18 & \\
\hline & & Hamburg, DEU & 09-2017 & & 19 & \\
\hline & & Duisburg, DEU & 09-2017 & 13,000 & 19 & \\
\hline & & Milan, ITA & 09-2017 & & 21 & \\
\hline - & Yingtan & Antwerp, BLX & 05-2018 & 11,000 & 16 & \\
\hline
\end{tabular}

Note: Authors' compilation based on information from Li et al. (2018) and additional online searches (including www.railfreight.com and www.chinaeuroperailwayexpress.com). 